\title{
Pembuatan Keputusan Etis pada Mahasiswa: Tema-Tema, Faktor- Faktor yang Memengaruhi dan Strategi Mengatasi Dilema
}

\author{
Retno Kumolohadi ${ }^{1}$, Frieda Mangunsong ${ }^{2}$, Julia Suleeman ${ }^{3}$ \\ ${ }^{1,2,3}$ Fakultas Psikologi, Universitas Indonesia, Depok, Indonesia \\ ${ }^{1}$ Fakultas Psikologi dan Ilmu Sosial Budaya, Universitas Islam Indonesia, Yogyakarta, Indonesia \\ e-mail: retno.kumolohadi@ui.ac.id
}

\begin{abstract}
The aimed of this study was to explore ethical and unethical decisions themes, determinant factors, and strategies for coping the dilemma. The method used in this research was qualitative with phenomenology approach. Data were collected by a semi open ended questionnaire $(N=124)$, and focus group discussions $(N=14)$. The results showed ethical themes regarding problems with attendance in class and academic assignments, problems with parents, problems with friend, and issues of public order. The dominant personal factors were moral character and religiosity. While situational factors included obedience to authority, fear of other people's dislike, conformity, sanctions, and opportunity. Coping the ethical dilemma were focused on one or more strategies which consist of risks and consequences, legal and religious principles, advice from others (friends, parents), and character. This research has theoretical and practical implications for the development of ethical decision-making model as input in the teaching and learning process in higher education.
\end{abstract}

Keywords: ethical themes, ethical decision making, dilemma coping strategies

\begin{abstract}
Abstrak
Penelitian ini bertujuan untuk mengeksplorasi tema-tema pembuatan keputusan etis, faktor-faktor yang memengaruhi dan strategi-strategi mengatasi dilema. Metode yang digunakan dalam penelitian yaitu kualitatif dengan pendekatan fenomenologi. Data dikumpulkan dengan kuesioner semi terbuka ( $\mathrm{N}=124)$, dan diskusi kelompok terfokus $(\mathrm{N}=14)$. Hasil penelitian menunjukkan tema etis menyangkut masalah kehadiran di kelas dan tugas akademik, masalah dengan orang tua, masalah dengan teman, masalah ketertiban umum. Faktor personal yang paling banyak memengaruhi yaitu karakter moral dan religiusitas. Sementara itu faktor situasional mencakup kepatuhan terhadap otoritas, khawatir ketidaksukaan orang lain, konformitas, sanksi, dan kesempatan. Cara mengatasi dilema etis difokuskan pada satu atau lebih strategi yang terdiri dari risiko dan konsekuensi, prinsip hukum dan agama, saran atau masukan orang lain (teman, orang tua), dan karakter. Penelitian ini berimplikasi secara teoretis dan praktis untuk pengembangan model pembuatan keputusan etis serta sebagai masukan dalam proses belajar mengajar di Perguruan Tinggi.
\end{abstract}

Kata Kunci: tema etis, pembuatan keputusan etis, strategi mengatasi dilema

\section{Pendahuluan}

Mahasiswa memiliki tugas dan tanggung jawab akademik dan non akademik. Selain kuliah, mahasiswa juga melaksanakan tugas akademik lainnya yaitu membaca dan memahami buku teks, mencatat, presentasi, diskusi, tugas menulis (laporan dan makalah), serta ujian. Mahasiswa juga melaksanakan tugas dan tanggung jawab non akademik yang mencakup urusan pribadi dan sosial untuk keluarga, pergaulan dengan teman serta ikut menjaga ketertiban dalam masyarakat.

Tidak jarang terjadi benturan waktu dan kepentingan antara beberapa tugas dan tanggung jawab yang menyebabkan dilema dalam pembuatan keputusan. Pembuatan keputusan pada saat dilema etis terjadi, ternyata seringkali tidak tepat, misalnya seharusnya hadir kuliah pagi sesuai jadwal, namun terlambat bangun karena pada malam harinya berkumpul hingga larut malam bersama teman-teman. Hal ini 
mengakibatkan mahasiswa menjadi terlambat pergi ke kampus bahkan mungkin memilih absen. Kebiasaan buruk lainnya adalah kebiasaan mengebut di jalan. Mahasiswa berdalih jika tidak cepat-cepat akan terlambat kuliah namun bila "ngebut" di jalan tidak bisa dihindari akan melanggar tata tertib lalu lintas. Akhirnya mahasiswa memilih "ngebut" demi mengejar waktu agar mengurangi keterlambatan.

Di Indonesia, masalah pelanggaran etis telah menjadi perhatian pemerintah. Berdasarkan penelitian yang dilakukan oleh Kementerian Riset, Teknologi, dan Pendidikan Tinggi, sejak 2015 plagiarisme telah terjadi di banyak kampus secara sistematis dan skala besar (Wirawan, 2017). Selain plagiarisme, ditemukan pula kasus lain pada mahasiswa seperti pelecehan seksual dan kekerasan dalam pacaran (Widyasari \& Aryastami, 2018) serta perundungan (Muzdalifah \& Afriyanto, 2014). Yogyakarta, sebagai kota pelajar tempat para pelajar dari berbagai daerah datang untuk belajar pun tidak lepas dari isu-isu nasional tentang pelanggaran etis ini. Posisi kota Yogyakarta menjadi sangat strategis karena dapat menjadi barometer kondisi mahasiswa pada umumnya di Indonesia.

Mahasiswa, menurut Hurlock (2006) telah mencapai usia dewasa. Usia dewasa mulai dari usia 18 tahun sampai dengan usia 40 tahun dan pada usia tersebut dapat digolongkan sebagai usia dewasa awal. Hughes dan McCabe (2006) mengatakan bahwa orang dewasa diharapkan sudah dapat membuat estimasi akurat mengenai keuntungan dan kerugian serta mematuhi peraturan tentang nilai-nilai sosial di masyarakat, apalagi mendapat pendidikan di perguruan tinggi. Hughes dan McCabe, (2006) menambahkan bahwa ketika orang dewasa belajar di Perguruan Tinggi, individu tidak hanya memperoleh materi untuk meningkatkan kapasitas intelektualnya, tetapi juga meningkatkan moralitas, pendidikan kewarganegaraan, serta pembuatan keputusan etis.
Pembuatan keputusan etis merupakan proses dan hasil dari evaluasi kognitif individu untuk tunduk pada norma perilaku yang baik. Individu menimbang, kemudian menentukan salah satu pilihan dari sekian banyak alternatif pilihan yang ada. Akhirnya dalam diri individu muncul motivasi bertindak kemudian merealisasikan dalam bentuk perilaku nyata (Treviño dkk., 2014).

Treviño dkk. (2014) menguraikan bahwa bentuk dari suatu keputusan etis berdasarkan pedoman atau dasar acuan yang digunakan ada tiga yaitu: (1) keputusan normatif berdasarkan aturan, tata tertib, peraturan dan perundang-undangan, misalnya tata tertib berlalu lintas, peraturan akademik, dan lain-lain; (2) keputusan terstandar berdasarkan nilai-nilai minimal bermasyarakat yang tidak tertulis: hormat menghormati, toleransi, kepedulian, kejujuran, dan lain-lain; (3) keputusan yang luar biasa (extraordinary) berdasarkan nilai-nilai kemanusiaan, misalnya menjadi donatur tetap suatu panti, menghibahkan tanah untuk pendirian tempat ibadah, korupsi atau antikorupsi dan lain-lain.

Pembuatan keputusan tidak etis yang mungkin dilakukan mahasiswa berkaitan dengan riwayat masa lalu. Tidak jarang hal itu sudah dilakukan sebelum masuk kuliah. Harding dkk. (2004) menemukan bahwa menyontek di kampus terkait dengan menyontek di tingkat sekolah menengah. Individu juga terdeteksi melakukan perilaku menyimpang seperti mencuri dan berbohong. Senada dengan hal itu, penelitian Blankenship dan Whitley (2000) juga menemukan bahwa menyontek di kampus konsisten dengan perilaku ilegal, penyalahgunaan NAPZA, dan perilaku berisiko tinggi di jalan seperti mengebut, tidak membawa alat keselamatan berkendara dan surat ijin kendaraan bermotor.

Pada generasi milenial, cakupan pembuatan keputusan etis lebih bervariasi aktivitasnya. Yeung dan Keup (2009) dalam studinya terhadap 1.568 mahasiswa 
yang mengisi angket, meninjau persepsi mahasiswa itu sendiri maupun persepsi mahasiswa lain tentang pembuatan keputusan etis teman-temannya. Keputusan etis yang dibuat oleh mahasiswa secara spesifik berdasarkan aktivitas yang dilakukan dapat berupa akademik, sosial, dan aktivitas yang berhubungan dengan pemanfaatan sarana prasarana serta teknologi informasi yang berguna untuk mempermudah aktivitas baik akademik maupun non akademik.

Berdasarkan penelitian Yeung dan Keup (2009), pada aktivitas yang menyangkut dimensi sosial, indikator pelanggaran etis yang muncul adalah kebiasaan buruk mahasiswa di kampuskampus luar negeri tentang penggunaan identitas diri palsu untuk masuk ke bar dengan kebiasaan minum alkohol dan pergaulan bebas, pelanggaran sistem elektronik dan sarana prasarana kampus. Di Indonesia, tidak muncul hal-hal tersebut dan kemungkinan indikator aktivitas sosialnya berbeda.

Selain itu, terkait pemanfaatan teknologi informasi mutakhir, penghargaan terhadap hak cipta belum tersosialisasi dengan baik. Padahal, Undang-Undang tentang Hak Cipta telah ada sejak tahun 2002 (Undang-Undang Nomor 19) Hal ini menyebabkan perilaku seperti mengunduh materi yang memiliki hak cipta tanpa membayar atau memasang perangkat lunak tanpa izin di komputer pribadi dan pelanggaran etis lainnya yang terjadi berkaitan dengan internet, seringkali tidak dipermasalahkan.

Beberapa di antara pelanggaran etis yang dilakukan bahkan dianggap biasa. Heckler dan Forde (2015) merekrut 527 mahasiswa di Amerika Serikat untuk terlibat dalam penelitian tentang pencarian sumber referensi di internet. Studi ini menunjukkan bahwa $74.9 \%$ dari peserta menganggap plagiat sebagai hal yang umum, dan tidak memiliki kekhawatiran mengenai hal itu. Dalam studi ini juga ditemukan terkait dengan pencarian sumber di internet maupun berbagai software didapatkan fakta bahwa mahasiswa merasa bebas untuk mencari banyak hal di internet dan mengambil materi tanpa ijin karena materi di internet dapat dianggap sebagai sumber daya publik (Heckler \& Forde, 2015).

Pembuatan keputusan etis memiliki efek yang berarti pada individu dan tempat individu berada. Individu yang membuat keputusan etis cenderung merasakan efek positif, dan sebaliknya. Cooper dan Chen (2014) menyatakan bahwa individu akan mencapai kesejahteraan psikologis ketika memperhatikan hal-hal etis. Ottaway dkk. (2017) mengatakan bahwa mencegah perilaku tidak etis sangat penting dalam menjaga nama baik individu, dan tempat individu berada. Ketika membuat keputusan etis berarti individu memenuhi standar norma yang baik.

Banyak penelitian telah menunjukkan bahwa sejumlah faktor personal dan situasional berkontribusi terhadap pembuatan keputusan etis (Treviño dkk., 2014). Menurut Treviño dkk. (2014), faktor personal menunjukkan kualitas yang relatif stabil dari seseorang sehingga memengaruhi perilakunya, sedangkan faktor situasional merupakan atribut situasi sekitar saat perilaku itu terjadi. Dengan kata lain yaitu situasi yang memicu atau memunculkan perilaku tertentu.

Faktor personal berupa: kondisi neurocognitive (Reynolds, 2006), intuisi (Haidt, 2001; Sonenshein, 2007); pemahaman terhadap isu etik (Gopinath, 2008), love of money, religiusitas (Perrin, 2000), kepribadian big five (Kalshoven dkk., 2011), harga diri, religiusitas, kepribadian machiavelian, love of money dan persepsi terhadap integritas figur otoritas (Tang \& Liu, 2012), emosi (Kouchaki \& Desai, 2015; Ruedy dkk., 2013), serta karakter moral (Cohen \& Morse, 2014).

Faktor situasional terdiri dari pengaruh keluarga (Duh dkk., 2010), intensitas dengan figur otoritas (Cialdini \& Goldstein, 
2004), konformitas yang dilatarbelakangi oleh agama (Brauer dkk., 2013). Faktor organisasi berupa: sosialisasi kode etik melalui program intervensi etik (Beeri dkk., 2013); Faktor situasional mampu memfasilitasi penyebaran ide, nilai, norma, sikap dan perilaku. Individu bahkan kadang tidak lagi memedulikan benar atau salah perilaku dari kelompok sosialnya (Harris dkk., 2012). Kelompok mayoritas, orang yang ahli atau memiliki hubungan yang bermakna, misalnya atasan atau teman yang disegani, akan lebih didengar daripada orang lain (Harris dkk., 2012).

Faktor personal seperti dikemukakan oleh Treviño dkk. (2014) berupa locus of control, kemampuan individu untuk pengaturan diri, dan identitas moral, sama halnya dengan faktor situasional yang terdiri dari sistem yang berlaku dalam organisasi, tekanan kerja, konflik peran, iklim etis, budaya etis, hadiah dan hukuman, dan peluang atau kesempatan. Sayangnya, para ahli dan peneliti tersebut masih terbatas dalam mempelajari gambaran faktor-faktor personal dan situasional. Konteks sosial budaya, interaksi antar faktor dan maknanya dalam menentukan strategi pembuatan keputusan etis belum terlalu tergali.

Berdasarkan paparan terkait penelitianpenelitian yang telah dilakukan, peneliti tertarik untuk lebih mendalami mengenai hal ini. Penelitian serupa baru sebatas mengkaji tentang pembuatan keputusan etis dalam konteks mahasiswa di Barat dengan perkembangan situasi sosial dan teknologi mutakhir. Sementara itu, penelitian ini menjadi sangat penting dan berkontribusi besar untuk dapat menemukan dinamika pembuatan keputusan etis, pada mahasiswa di Indonesia, terutama dalam hal isu-isu etis yang muncul dalam tema-tema, faktorfaktor dan strategi ketika membuat keputusan etis yang tentu saja lebih spesifik khas Indonesia. Keputusan etis sering disertai dengan dilema dalam prosesnya. Dengan demikian penelitian ini bertujuan untuk memperoleh gambaran tema, faktor- faktor yang memengaruhi dan strategi dalam membuat keputusan etis pada mahasiswa.

\section{Metode Penelitian}

Penelitian ini menggunakan metode kualitatif dengan pendekatan fenomenologi. Fenomenologi tepat digunakan dalam penelitian ini karena berupaya untuk menggambarkan, memahami, dan menafsirkan makna dari pengalaman individu terhadap kehidupannya sebagai mahasiswa. Pertanyaan penting penelitian fenomenologi yaitu: "Apa yang subjek alami dan bagaimana mengalaminya?".

Tabel 1

Karakteristik Subjek Penelitian ( $=124)$

\begin{tabular}{|c|c|c|c|}
\hline Kriteria & Kategori & Jumlah & $\%$ \\
\hline \multirow[t]{2}{*}{ Jenis Kelamin } & Laki-Laki & 56 & 45.16 \\
\hline & Perempuan & 68 & 54.84 \\
\hline \multirow[t]{4}{*}{ Usia } & $18<X \leq 20$ & 67 & 54.03 \\
\hline & $20<X \leq 25$ & 56 & 45.16 \\
\hline & $X>25$ & 1 & .8 \\
\hline & Rata-rata & 20,54 & \\
\hline \multirow[t]{2}{*}{ Pendidikan } & Sarjana & 84 & 67.74 \\
\hline & Pascasarjana & 40 & 32.36 \\
\hline \multirow[t]{19}{*}{ Suku Bangsa } & Jawa & 77 & 62.09 \\
\hline & Melayu & 8 & 6.5 \\
\hline & Bugis & 4 & 3.22 \\
\hline & Batak & 2 & 1.61 \\
\hline & Sunda & 3 & 2.42 \\
\hline & Sasak & 3 & 2.42 \\
\hline & Cina & 2 & 1.61 \\
\hline & Betawi & 1 & .81 \\
\hline & Tobaru & 1 & .81 \\
\hline & Gorontalo & 1 & .81 \\
\hline & Madura & 1 & .81 \\
\hline & Ternate & 1 & .81 \\
\hline & Dayak & 1 & .81 \\
\hline & Banjar & 1 & .81 \\
\hline & Bendang & 1 & .81 \\
\hline & Ogan & 1 & .81 \\
\hline & Bali & 1 & .81 \\
\hline & Kutai & 1 & .81 \\
\hline & Tidak Diisi & 14 & 11.29 \\
\hline \multirow[t]{4}{*}{ Agama } & Islam & 120 & 96.77 \\
\hline & Kristen & 2 & 1.6 \\
\hline & Katholik & 1 & .8 \\
\hline & Hindu & 1 & .8 \\
\hline
\end{tabular}


Subjek penelitian berjumlah 124 orang dari universitas negeri dan swasta, terdiri dari 40 mahasiswa dari satu universitas negeri (Fakultas Ilmu Pendidikan) dan 84 mahasiswa dari universitas swasta yang berlatar belakang agama (Fakultas Psikologi, Teknik, Hukum, Agama Islam) di Yogyakarta dan menggunakan FGD pada 14 mahasiswa pengisi angket. Adapun karakteristik subjek disajikan pada tabel 1 .

Penelitian ini terdiri dari dua tahapan. Pertama, subjek diminta untuk mengisi angket semi terbuka yang berjudul Ethical Decision Making (EDM). Dalam kuesioner EDM, subjek diminta untuk mengisi jawaban atas 12 pertanyaan dengan format pertanyaan yaitu: a) 2 pertanyan tertutup (nomor 1 dan 2) tentang pernah atau tidak mengalami situasi sulit dan dilema membuat keputusan yang pernah dialami. Contoh pertanyaan: "Apakah anda pernah mengalami situasi sulit untuk membuat suatu keputusan?"; b) 3 pertanyaan terbuka yang dijawab dengan uraian (nomor 3,11 , 12) mengenai pengalaman dilema membuat keputusan, dinamika proses interaksi antar faktor yang memengaruhi dan strategi dalam mengatasi dilema. Contoh pertanyaan: "Uraikan dinamikal proses yang terjadi serta faktor-faktor yang memengaruhi dalam diri dan lingkungan saat membuat keputusan etis"; c) 6 pertanyaan semi terbuka yang terdiri dari 1 pertanyaan (nomor 5) mengenai dampak psikologis dan 5 pertanyaan (nomor $6,7,8,9,10$ ) mengenai faktor-faktor yang memengaruhi pembuatan keputusan etis. Terkait faktor-faktor tersebut, subjek boleh memberikan jawaban lebih dari satu faktor dan tersedia opsi yang bisa diisi sendiri oleh subjek di luar jawaban yang tersedia. Contoh pertanyaan: "Faktor-faktor lingkungan seperti apa sajakah yang memengaruhi anda dalam membuat keputusan antara pilihan etis/ tidak etis" (boleh memilih lebih dari satu yang disebutkan berikut atau mengisi alternatif lain); d) 1 pertanyaan (nomor 4) yang meminta subjek untuk menilai taraf kenyamanan atau ketidaknyamanan secara psikologis dari 0-10 yang dialami ketika dilema dalam membuat keputusan etistidak etis. Jawaban 0 untuk netral, jawaban 1-4 bila merasakan ketidaknyamanan tingkat rendah, 5-7 bila tingkat sedang dan 8-10 tingkat tinggi. Contoh pertanyaan: "Seberapa tinggi tingkat kesulitan (skala 0 10) berkaitan dengan pembuatan keputusan yang dilematis tersebut di atas" (lingkari salah satu angka).

Angket EDM disusun berdasarkan professional judgement dari ahli yang kompeten terdiri dari satu orang ahli dalam bidang Psikometri, satu orang ahli bidang Psikologi Sosial, dan dua orang ahli bidang Pendidikan. Dasar penyusunan instrumen berasal dari konsep pembuatan keputusan etis beserta faktor-faktor yang memengaruhi dari Treviño dkk. (2014), untuk mengidentifikasi pengalaman berkaitan dengan pembuatan keputusan etis-tidak etis. Teori membekali peneliti dalam memfokuskan pertanyaan, namun demikian subjek penelitian masih dapat leluasa memberikan jawaban lain yang mungkin tidak terdapat dalam teori yang diacu. Hal ini dapat menjadi temuan dari penelitian.

Kedua, setelah mengisi angket EDM, 14 subjek penelitian yang dapat dihubungi dan memiliki waktu luang serta kesediaan diri, melakukan diskusi kelompok terarah (FGD). FGD digunakan dengan tujuan untuk memperoleh informasi tentang proses pembuatan keputusan. Subjek dibagi menjadi dua kelompok yang masingmasing didampingi oleh satu asisten peneliti. Sebelum FGD dimulai, subjek mengisi informed consent yang menggambarkan tujuan penelitian, dan memastikan kerahasiaan data mereka dan kesediaan berpartisipasi.

Analisis data dilakukan dengan langkah-langkah sebagai berikut: Pertama, data dari angket EDM yang berbentuk kuantitatif seperti nomor 6,7,8,9,10 dimasukkan ke dalam Microsoft Excel untuk analisis dalam bentuk distribusi 
frekuensi dan persentase. Kedua, tanggapan kualitatif dari diskusi kelompok terarah (FGD) dianalisis isinya dan dilakukan koding dengan menggunakan program NVivo versi 11.

Tabel 2

Tema-tema Etis dan Respon Perasaan yang Muncul pada Mahasiswa

\begin{tabular}{|c|c|c|c|}
\hline Tingkat & Tema-tema & $\Sigma$ & $\begin{array}{c}\text { Respon } \\
\text { Perasaan }\end{array}$ \\
\hline $\begin{array}{l}\text { Netral } \\
(0)\end{array}$ & $\begin{array}{l}\text { Hadir kuliah dan } \\
\text { ujian, tepat waktu } \\
\text { pengumpulan } \\
\text { tugas, tertib lalu } \\
\text { lintas, }\end{array}$ & 69 & $\begin{array}{l}\text { lega, puas, } \\
\text { nyaman, } \\
\text { tenang, tidak } \\
\text { bermasalah }\end{array}$ \\
\hline $\begin{array}{l}\text { Rendah } \\
(1-4)\end{array}$ & $\begin{array}{l}\text { Datang terlambat } \\
\text { saat kuliah dan } \\
\text { ujian }\end{array}$ & 4 & $\begin{array}{l}\text { biasa, sedikit } \\
\text { penyesalan } \\
\text { janji untuk } \\
\text { memperbaiki }\end{array}$ \\
\hline $\begin{array}{l}\text { Sedang } \\
(5-7)\end{array}$ & $\begin{array}{l}\text { Tidak hadir } \\
\text { kuliah, memalsu } \\
\text { tanda tangan } \\
\text { teman pada daftar } \\
\text { hadir, berbohong } \\
\text { dan konflik } \\
\text { dengan teman, } \\
\text { melanggar lalu } \\
\text { lintas, melanggar } \\
\text { jam malam, } \\
\text { kabur, minum } \\
\text { alkohol }\end{array}$ & 30 & $\begin{array}{l}\text { takut, } \\
\text { di bawah } \\
\text { tekanan, } \\
\text { tegang, } \\
\text { tidak } \\
\text { nyaman }\end{array}$ \\
\hline $\begin{array}{l}\text { Tinggi } \\
(8-10)\end{array}$ & $\begin{array}{l}\text { Berbohong pada } \\
\text { dosen dan orang } \\
\text { tua, bolos kuliah, } \\
\text { plagiat, rekayasa } \\
\text { anggaran, curang, } \\
\text { bullying, } \\
\text { berhubungan seks } \\
\text { sebelum menikah, } \\
\text { pencurian }\end{array}$ & 21 & $\begin{array}{l}\text { cemas, } \\
\text { khawatir, } \\
\text { penyesalan } \\
\text { suasana hati } \\
\text { yang buruk, } \\
\text { ketegangan, } \\
\text { bersalah, } \\
\text { situasi sulit, } \\
\text { tidak } \\
\text { berdaya, } \\
\text { takut dosa }\end{array}$ \\
\hline
\end{tabular}

\section{Hasil Penelitian dan Pembahasan}

\section{Hasil Penelitian}

Pengisian Angket EDM

Subjek pernah mengalami dilema memilih antara keputusan etis atau tidak etis. Ketika subjek dapat memecahkan masalah dan membuat keputusan etis, subjek merasa lega demikian pula sebaliknya. Data pada tabel 2 menunjukkan bahwa semakin berat suatu pelanggaran, semakin kuat pula respon perasaannya.

Selanjutnya, data dari kuesioner EDM menunjukkan faktor-faktor yang memengaruhi pembuatan keputusan etis dari faktor personal maupun situasional, baik yang dinyatakan dalam bentuk pilihan yang sudah tersedia, maupun mengisi berupa uraian yang memang belum ada dalam pilihan. Subjek dapat menyebutkan lebih dari satu pilihan, baik dalam faktor personal maupun situasional (tabel 3).

Pada faktor personal, subjek menyebutkan beberapa karakteristik yang sangat penting untuk membuat keputusan etis, yang terdiri dari aspek kognitif, afektif dan psikomotorik Pada faktor situasional, terutama dari lingkungan sekitar yang paling dekat dan bermakna. Sementara itu, faktor situasional lainnya yang terkait berupa sistem yang berlaku dan kesempatan. Pada faktor personal, subjek menyebutkan beberapa karakteristik yang sangat penting untuk membuat keputusan etis, yang terdiri dari aspek kognitif seperti pertimbangan konsekuensi masa depan dan pemahaman tentang masalah moral dan juga keterbukaan pada pengalaman. Subjek juga menekankan pentingnya pengaruh afektif dan psikomotorik seperti identitas moral yang sebenarnya menunjukkan konsep diri sebagai orang bermoral, kontrol diri, kejujuran, empati, keberanian seiring pula dengan pengambilan risiko, rasa malu dan bersalah, kesederhanaan, kemandirian dan kepuasan pribadi. Kekhawatiran tidak disukai, ketidakberdayaan serta kelelahan menunjukkan faktor personal yang akan melemahkan kemampuan diri sendiri. 
Pembuatan Keputusan Etis pada Mahasiswa: Tema-Tema, Faktor-Faktor yang Memengaruhi dan Strategi Mengatasi Dilema (Retno Kumolohadi, Frieda Mangunsong, Julia Suleeman)

Tabel 3

Distribusi Frekuensi Faktor-Faktor yang Memengaruhi Pembuatan Keputusan Etis $(N=124)$

\begin{tabular}{|c|c|c|c|}
\hline $\begin{array}{c}\text { Faktor-faktor yang } \\
\text { Memengaruhi }\end{array}$ & Kategori & $\mathrm{F}$ & $\%$ \\
\hline Konsekuensi masa depan & Personal & 73 & 58.87 \\
\hline $\begin{array}{l}\text { Dukungan, kontrol } \\
\text { keluarga }\end{array}$ & Situasional & 72 & 58.06 \\
\hline Religiusitas & Personal & 68 & 54.84 \\
\hline Identitas moral & Personal & 68 & 54.84 \\
\hline Kontrol diri & Personal & 55 & 44.35 \\
\hline Kejujuran & Personal & 51 & 41.13 \\
\hline Kesempatan & SItuasional & 50 & 40.43 \\
\hline Conscientiousness & Personal & 48 & 38.71 \\
\hline $\begin{array}{l}\text { Khawatir tak disukai, } \\
\text { kritik sosial }\end{array}$ & Situasional & 42 & 33.87 \\
\hline Ekonomi & Situasional & 41 & 33.06 \\
\hline Kepatuhan pada otoritas & Situasional & 40 & 32.26 \\
\hline Penghargaan dan sanksi & Situasional & 40 & 32.26 \\
\hline $\begin{array}{l}\text { Ikut-ikutan teman } \\
\text { (konformitas) }\end{array}$ & Situasional & 36 & 29.03 \\
\hline Machiavelian & Personal & 33 & 26.61 \\
\hline Kebiasaan & Personal & 30 & 24.19 \\
\hline Empati & Personal & 30 & 24.19 \\
\hline Keberanian & Personal & 30 & 24.19 \\
\hline Malu & Personal & 28 & 22.58 \\
\hline Adil & Personal & 28 & 22.58 \\
\hline Kepuasan pribadi & Personal & 26 & 20.97 \\
\hline Perilaku resiko tinggi & Personal & 24 & 19.35 \\
\hline $\begin{array}{l}\text { Pemahaman terhadap isu } \\
\text { etis }\end{array}$ & Personal & 20 & 16.13 \\
\hline Status sosial & Personal & 19 & 15.32 \\
\hline Rasa bersalah & Personal & 18 & 14.52 \\
\hline Kesederhanaan & Personal & 12 & 9.68 \\
\hline Ketidakberdayaan & Personal & 9 & 7.26 \\
\hline Terbuka pada pengalaman & Personal & 8 & 6.45 \\
\hline Kemandirian & Personal & 3 & 2.42 \\
\hline Kelelahan & Personal & 1 & .81 \\
\hline
\end{tabular}

Selain itu, subjek penelitian juga menyebut karakter tidak mau tahu dan tidak peduli orang lain, yang penting orang lain harus mengerti dirinya, suka potong kompas dan pragmatis. Dalam faktor sosial, dukungan keluarga adalah faktor yang paling berpengaruh, diikuti oleh pengaruh otoritas dan teman. Sementara itu, sistem dalam organisasi seperti penghargaan dan konsekuensi atau sanksi, kebiasaan, dan kesempatan untuk melakukan perilaku etis atau tidak etis sama pentingnya dengan faktor personal dan sosial.

Subjek memiliki strategi tertentu dalam mengatasi konflik atau dilema etis. (tabel 4A,4B,4C,4D), sementara yang lain menggabungkannya (tabel 4E).
Tabel 4A

Strategi yang Berasal dari Orang Lain (Jumlah

Pemilih = 8)

\begin{tabular}{l}
\hline Strategi Terfokus Masukan Orang Lain \\
\hline 1. Upaya diskusi dengan orang tua dengan \\
meyakinkan diri sendiri \\
2. Lihat keadaan lingkungan, pendapat orang \\
tua dan keluarga serta kemampuan mereka \\
3. Tidak malu meminta kepastian orang lain \\
4. Keterbukaan dengan orang tua \\
5. Mintalah solusi kepada orang tua / teman \\
6. Mintalah petunjuk dari orang terdekat \\
7. Coba terbuka pada orang tua dan teman \\
dekat
\end{tabular}

Tabel 4B

Strategi Utama Mahasiswa Terkait Risiko dan Konsekuensi (Jumlah Pemilih = 11)

Strategi Terfokus pada Risiko dan Konsekuensi

1. Melihat konsekuensi, perlu atau tidak perlu

2. Hati-hati, jangan terburu-buru, pikirkan sebelum bertindak

3. Berpikir tentang positif negatif, menimbang keputusan,

4. Introspeksi, dengan mempertimbangkan risiko dan sanksi

5. Tidak mengulangi kesalahan

6. Pikirkan baik-baik agar tidak ada penyesalan yang muncul

7. Pikirkan konsekuensinya ke depan

8. Selalu pikirkan konsekuensi jangka panjang

9. Identifikasi risiko, tentukan tindakan dari awal hingga selesai secara bertahap

10. Mengingat konsekuensi untuk masa depan, rencana ke depan meskipun hasil tidak tahu

11. Strategi awal menentukan dan langkahlangkah ke depan lebih matang

12. Mencari tips untuk sukses

13. Berpikir jernih

14. Memperhatikan kerugian dan manfaatnya

15. Memikirkan dampak di masa depan, konsisten dan tidak mudah terpengaruh

16. Belajar dari pengalaman

17. Lakukan yang terbaik dalam hidup, berguna dan membuat bahagia, jangan pikirkan kata orang

18. Prediksikan apa yang akan terjadi

19. Lihatlah situasi yang terjadi dan konsekuensinya di masa depan

20. Baca instruksi dan arah yang benar

21. Skala prioritas, memprioritaskan yang penting dan mendesak serta dibutuhkan

22. Pertahankan tujuan awal dan harus mempertimbangkan situasinya, lakukan yang terbaik

23. Berpikir positif dan berpegang teguh pada prinsip-prinsip yang telah dibangun 
Tabel 4C

Strategi Utama Mahasiswa berasal dari Hukum, Agama, Etika (Jumlah Pemilih = 18)

Strategi Terfokus pada Norma Hukum, Agama, Etika

1. Meyakinkan diri dengan norma hukum

2. Pahami aturan hukum tentang keputusan tersebut

3. Punya prinsip hidup

4. Buat keputusan berdasarkan norma

5. Yang paling dipegang agama dan meminta nasihat

6. Pembelajaran yang asertif, bersandar pada kata yang insya Allah dengan harapan apa yang dihasilkan atas izin-Nya dan menjadi baik

7. Pegang prinsip yang benar dan prinsip agama yang kuat

8. Tetap berpegang pada ajaran agama dan aturan

9. Pengetahuan berdasarkan kitab suci

10. Bergaullah dengan tepat sesuai dengan norma dan kebiasaan agama

11. Jalan lurus

12. Dasar agama, realitas sosial, prinsip penanaman akan dipanen

13. Lebih dekat dengan Tuhan, taat dan memegang perintah-Nya untuk berdoa untuk yang terbaik

Tabel 4D

Strategi Utama Mahasiswa yang Berasal dari Karakter dan Pengalaman (Jumlah Pemilih $=54)$

Strategi Terfokus pada Karakter

1. Percaya dengan diri sendiri dan istiqomah (sikap teguh)

2. Berani mengambil risiko, memperkuat mental \& percaya bahwa langkah yang diambil adalah yang terbaik

3. Perkuat kontrol diri

4. Tidak hanya memikirkan diri sendiri tetapi juga orang lain

5. Pilih untuk tidak berada dalam situasi itu (hindari) dan menjadi bijak

6. Yakinkan diri dengan prinsip dalam diri agar tidak khawatir

7. Bersikap tegas dengan diri sendiri segera melihat norma-norma yang berlaku dan mengesampingkan kepentingan pribadi

8. Manajemen diri

9. Pilih sesuai dengan keadaan aktual

10. Bangun karakter dan hilangkan kemalasan

11. Tentukan langkah-langkahnya dengan tegas, berdirilah teguh dan hati-hati di langkah selanjutnya

12. Belajar dari pengalaman, tepat waktu, disiplin, kerja keras, beramal membuat segalanya lebih mudah

13. Evaluasi diri dengan melihat dampak dan sikap yang telah diambil

14. Tegas dan memiliki prinsip hidup yang tidak mudah dipengaruhi

15. Kendalikan diri, dan alihkan pikiran
Tabel 4E

Berbagai Strategi Gabungan pada Mahasiswa $($ Jumlah Pemilih $=15)$

\begin{tabular}{|c|c|}
\hline Pernyataan & Strategi Gabungan \\
\hline $\begin{array}{l}\text { 1. Berkomunikasi dengan } \\
\text { hati nurani yang } \\
\text { sebenarnya baik, kontrol } \\
\text { diri berdasarkan nilai- } \\
\text { nilai agama dan } \\
\text { kesopanan }\end{array}$ & $\begin{array}{lr}\text { Karakter } & \text { digabung } \\
\text { dengan norma } & \text { nona } \\
\text { agama dan etika }\end{array}$ \\
\hline $\begin{array}{l}\text { 2. Mengusahakan agar } \\
\text { mapan secara ekonomi } \\
\text { dan tidak meninggalkan } \\
\text { iman }\end{array}$ & $\begin{array}{l}\text { Konsekuensi } \\
\text { digabung dengan } \\
\text { norma agama }\end{array}$ \\
\hline $\begin{array}{l}\text { 3. Tetapkan standar wajib } \\
\text { dan sunnah, untung dan } \\
\text { rugi, lalu menguatkan } \\
\text { hati untuk ambil } \\
\text { keputusan }\end{array}$ & $\begin{array}{l}\text { Norma } \\
\text { digabung } \\
\text { karakter }\end{array}$ \\
\hline $\begin{array}{l}\text { 4. Berdoa dan percaya diri, } \\
\text { masa bodoh kata orang } \\
\text { lain }\end{array}$ & $\begin{array}{l}\text { Norma Agama } \\
\text { digabung karakter }\end{array}$ \\
\hline $\begin{array}{l}\text { 5. Jangan terlalu banyak } \\
\text { pertimbangan, percaya } \\
\text { diri dan siap menerima } \\
\text { risiko, meminta }\end{array}$ & $\begin{array}{lr}\text { Karakter, } & \text { Risiko } \\
\text { dan konsekuensi } \\
\text { digabung norma } \\
\text { agama }\end{array}$ \\
\hline
\end{tabular}

pertolongan Tuhan, ada rencana dan tujuan untuk setiap pengalaman

6. Mendengarkan masukan, sabar, tenang, minta petunjuk dari Allah SWT dan keluarga besar

7. Berkonsultasi dengan orang tua agar orang tua selalu berdoa untuk kebaikan dan mengingat penciptanya

8. Berpikir luas di masa depan bersama dengan risiko, bersikap mawas diri dan menjaga nama baik keluarga

9. Pertimbangkan orang tua, evaluasi perilaku

10. Mendengarkan hati nurani, berpikir logis dan dewasa, mendengarkan saran orang tua, teman dekat, dan kendali diri

11. Belajar dari pengalaman, tepat waktu, disiplin, kerja keras, beramal sholeh membuat segalanya lebih mudah 
Berdasarkan pernyataan dari subjek penelitian pada angket EDM, total sebanyak 106 subjek telah memilih strategi tertentu dalam menghadapi konflik atau dilema etis. Terdapat 18 orang yang tidak mengisi bentuk strateginya. Strategi ini dapat menjadi pedoman perilaku dan hal itu berbeda-beda antara satu dengan yang lain. Strategi dapat dikategorikan menjadi lima fokus, yaitu: fokus pada masukan orang lain sebanyak 8 orang, fokus pada risiko dan konsekuensi (manfaat atau kerugian, positif negatif) sebanyak 11 orang, fokus pada prinsip norma hukum, agama dan etika sebanyak 18 orang, fokus pada karakter dan pengalaman sebanyak 54 orang, fokus pada berbagai tema strategi gabungan yang komprehensif sebanyak 15 orang.

\section{Diskusi Kelompok Terarah}

Data dari diskusi kelompok terarah (FGD) menunjukkan hasil yang serupa dengan data dari kuesioner EDM, terutama pada tema yang tidak etis dan dampak psikologisnya. Subjek penelitian mengaku berpikir sebelum bertindak, meskipun kadang-kadang menghadapi konflik dalam prosesnya.

\section{Tema-Tema Etis}

Berikut ini adalah beberapa pernyataan dari subjek penelitian mengenai tema etis yang berkaitan dengan akademik (Tema Etis Akademik/ TEA), dilema yang dihadapi dan alasan memilih keputusan.

"Kalau saya pernah mengalami dilema antara mau dititipi absen atau tidak. Saya tidak suka titip absen dan nggak mau kalau ada teman titip absen. saya bilang sorry...nggak bisa. Tapi ternyata suatu saat waktu saya tidak masuk ada teman yang baik hati ngabsenin. saya kaget kok presensi saya full, ...Akhirnya diputuskan membalas kebaikan teman tersebut untuk menandatangani pas ybs. tidak masuk, hanya untuk balas budi saja. Tahu kalau hal itu melanggar aturan" (TEA, L, 18-27)
"Saya sih pegang prinsip aja....bilang tidak usah menandatangani, tidak minta tanda tangan di presensi, siapapun yang titip tidak akan ditandatangani...Dilema juga sih tapi kuat-kuatan, risiko dipikir....akut gimana nanti kalau kerja terus jadi kebiasaan.." (TEA, L, 28-32)

"Sebelum saya memutuskan untuk bolos, saya mempertimbangkan kerugian dan keuntungan. Apakah ada kesempatan? Jika saya tidak punya waktu untuk menghadiri kuliah, saya akan masuk kelas. Tetapi, jika tidak ada orang yang mengambil alih tanggung jawab dari kegiatan kampus, saya akan bolos kelas. Terkadang saya tidak yakin untuk memutuskan. Saya memutuskan untuk menghadiri kuliah karena saya tahu bahwa tingkat kehadiran saya di kelas kurang dari $25 \%$. Jika siswa absen di lebih dari $25 \%$ dari total sesi, mereka tidak akan dapat mengikuti ujian" (TEA, Y, 21-29)

"Saya sering melihat tulisan orang lain karena saya tidak percaya diri dengan pemikiran saya sendiri dan memiliki banyak tugas .... jadi saya kadang terjebak pada situasi tidak ada waktu lagi ... Tapi, saya menyadari bahwa saya harus mengubah perilaku saya. "(TEA, Y, 37-40)

Tema-tema yang muncul dalam pelanggaran etis berupa membolos kuliah, menitip presensi, dan plagiat. Ketika subjek akan membuat keputusan, subjek sebenarnya menyadari, kemudian mempertimbangkan segala sesuatunya. Subjek penelitian mengungkapkan dilema, sampai akhirnya menetapkan pilihan. Terdapat pemikiran lain yang menjadi alasan pembenar dari keputusannya tersebut.

Selain tema-tema akademik, terdapat tema-tema lain yang bersifat non akademik menyangkut permasalahan sosial seperti bullying, pelanggaran lalu lintas, minumminuman keras bahkan ada ide bunuh diri (Tema Etis Sosial/TES).

"Saya pernah melakukan bullying, membakar sepeda teman saya, jika saya ingat itu, saya malu dan memiliki konflik 
batin setelah memikirkan hal itu. Jadi, saya selalu ingat untuk berpikir dulu dalam segala hal sebelum bertindak" (TES, L. 4344)

"Sama seperti kebanyakan orang juga melanggar lalu lintas ... tidak ada masalah selama tidak ada yang mengingatkan kita dengan bunyi klakson atau teriakan." (TES, Y, 32-36)

"Teman ngajak minum minuman keras. cicipin sedikit karena penasaran tapi moralitas agama membuat menyesal apalagi ingat bahwa 40 hari tidak diterima sholatnya, waktu itu agama terabaikan" (TES, Y, 108-111)

"Aku dulu korban bullying dan masalah yang lain...Beberapa kali survive untuk itu...Waktu melakukan tidak ingat....",...Terus terang aku dulu pernah mencoba bunuh diri. Semua agama melarang bunuh diri. Karena ingat Tuhan nggak jadi...Cuman ya itu...beberapa kali pernah ada waktu dimana tidak ingat. Orang mau suicide butuh dukungan. Kalau ada pikiran aneh-aneh ....aku segera deketin keluarga atau teman." (TES, L, 3638, 50-55)

Konsekuensi dari perbuatan yang dilakukan khususnya ketika melakukan pelanggaran, ternyata bisa berbeda Pada satu pihak dapat muncul rasa malu, menyesal, dan konflik batin sebab bertentangan dengan norma sosial dan agama, namun demikian ada juga yang bersikap masa bodoh, selagi orang tidak merasa terganggu. Hal ini tentu perlu diwaspadai ketika menjadi suatu kebiasaan.

Penelitian ini menunjukkan bahwa subjek membiarkan pemikiran yang keliru dan berdalih dengan suatu alasan yang logis. Subjek ada yang bahkan meminta orang lain untuk memahami pikirannya (Respon pikiran/RP).

"Bagi saya etis atau tidak etis itu dilihat dulu menguntungkan atau tidak bagi kita, jika menguntungkan sekalipun melanggar itu tidak kenapa-kenapa. $\quad \mathrm{Ya}$ kita tinggal meyakinkan orang lain saja bahwa pilihan kita benar....memang kedengarannya egois" (RPE, L, 14-17)

"Saya tahu bahwa saya melanggar aturan, tetapi saya melakukannya karena saya ingin membalas kebaikan teman saya yang telah membantu saya menandatangani daftar hadir. Saya sebenarnya tidak menyukai perilaku ini, saya pikir itu benar untuk mengikuti ideologi seseorang tetapi saya juga memiliki hati nurani terhadap kebaikan dari orang lain" (RPE, L, 18-27)

Bagi mahasiswa yang menyadari identitas diri sebagai mahasiswa, maka sebelum bertindak akan memikirkan terlebih dulu identitas tersebut untuk selanjutnya berhati-hati dalam bertindak (Identitas Mahasiswa/ IM).

"Membuat keputusan adalah bagian dari proses pembelajaran sebagai mahasiswa. Kita harus berpikir jernih. Suatu kali saya memperjuangkan idealisme saya dengan membuat naskah tentang seseorang yang menyalahgunakan wewenangnya, dan saya mendapatkan konsekuensinya dengan diteror. Saya tidak peduli. Saya tidak takut karena saya punya beberapa bukti. Ternyata kasusnya terungkap. Saya menyimpulkan bahwa perlu untuk menjadi idealis, menghadapi masalah dan tidak terintimidasi terutama jika memiliki bukti. Kita tidak boleh menggadaikan kebenaran" (IM, Y, 83-95)

Subjek penelitian mengungkapkan bahwa sebagai mahasiswa itu perlu idealis dan menjunjung tinggi kebenaran.

\section{Peran Faktor Situasional}

Data menunjukkan bahwa faktor situasional memengaruhi proses pembuatan keputusan etis. Faktor situasional (FS) merupakan faktor di luar diri individu yang memengaruhi perilakunya seperti: lingkungan teman, lingkungan masyarakat, sistem yang berlaku, kesempatan dan lainlain".

"Sering nerobos tahu ada aturan hukum ngebut karena sepi, Ada rasa salah apalagi kalo ada yang sadar lihat, Jika 
kesempatan cukup sebenarnya bisa tepat waktu" (FS, Y, 18-20)

"Menurutku ya seseorang itu..apapun itu nggak usah idealis banget lah kalau mau jujur pada diri kita sendiri. Misalnya ya nerobos lampu merah kalau nggak buruburu, ada celah, jadinya nggak mau tahu aturan. Kalau bisa bertahan, orang itu hebat...." (FS, L, 45-50)

"Dulu disiplin...tapi ngelihat temanteman secara nggak langsung kebawa. Kalau mau bolos lihat-lihat dulu kan kalau kuliah itu sudah tertata termasuk kita boleh absen berapa banyak ..." (FS, Y, 56-61)

Berbagai alasan disebutkan subjek ketika melanggar yaitu: melanggar lalu lintas karena sepi, buru-buru dan ada celah. Sementara itu bolos kuliah karena toleransi bolos masih ada sampai batas frekuensi tertentu. Subjek juga menyampaikan bahwa pengaruh orang lain yang juga melakukan hal yang sama memegaruhi kecenderungan melanggar.

Subjek penelitian ada keinginan menolak pengaruh dari orang lain terutama dari teman, orang tua, dan orang lain yang signifikan. Namun demikian, ada perkecualian untuk pengaruh orang tua. Perkataan orang tua berusaha untuk dipenuhi karena rasa tanggung jawab terhadap orang tua yang sudah menyekolahkan.

"Kadang ada kejadian orang yang etis atau tidak etis itu karena kurang asertif, kurang jujur pada orang lain dan lebih mendahulukan kepentingan orang lain. Sulit asertif dapat membuat kita jadi tidak melihat kondisi diri sendiri...misalnya keputusan akhirnya kita limpahkan ke orang lain... ke orang tua misalnya. Dalam berteman karana takut orang lain kecewa, maka kita diam saja "(FS, L, 56-62)

"Mustinya kita berani bilang ya...karena kalau dipendam....akhirnya memuncak tanpa disadari malah keluar perkataan dan perilaku yang membuat orang lain tersinggung. Butuh tamparan dari orang lain untuk tegas, kalau nggak suka bilang nggak suka walaupun orang itu bisa marah-marah" (FS, L, 63-67)

"Tapi kalau saya sih nggak kayak gitu juga ya. Nggak bisa kalau sama orang tua....inginnya memenuhi keinginan orang tua...Selama kuliah ikutin aturan belajar tetap belajar bukan seneng-seneng. Soal titip absen kalo aku nggak mau titip absen tapi kalau ada yang titip ya nggak papa dipenuhin. Sejauh ini tidak ada kerugian, jalani aja ntar lupa sendiri, Kalau bingung serahkan keputusan ke orang lain" (FS, L, 68-76)

Dalam persepsi subjek penelitian, bila makna dan pemahaman tentang isu etis itu salah (Makna Etis/ ME), maka dapat menjadi peluang untuk melanggar aturan.

"Perlu komunikasi agar tidak dikira sebagai sesuatu yang tidak etis. Waktu saya KKN bersamaan dengan handle acara organisasi. Mana yang diplih untuk didahulukan dan terpaksa tidak hadir kegiatan yang lain Akhirnya pilih KKN dengan pertimbangan kalau ditunda bakalan ribet ke depannya, namun saya mengkomunikasikan pada organisasi dan mereka mau memahami ketidakhadiran saya." (ME, Y, 126-132)

"Saya menambahkan pemahaman juga penting. Contohnya kita melanggar lalu lintas jika pemahaman kita menganggap hal itu dosa pasti tidak mau melanggar. Memahami lalu kintas merupakan kebijakan dalam suatu negara dan jika melanggar akan menghancurkan sistem yang telah dibangun, tentu lain jadinya. Pemahaman penting dalam menentukan mau etis atau tidak." (ME, Y, 131-137)

Selain itu, subjek benar-benar memperhitungkan imbalan dan konsekuensi (Imbalan dan Konsekuensi/ IK) atas apa yang akan mereka terima ketika patuh. Beratnya konsekuensi dalam bentuk hukuman merupakan pertimbangan penting.

"Sebelum saya melanggar aturan, saya akan melihat dulu siapa dosennya dan apa imbalan dan konsekuensinya" (IK, L, 93-94) 
"Cuma kadang bisa muncul perasaan nggak enak sama dosennya apalagi dosennya baik, tugas bisa menyusul". (IK, $\mathrm{Y}, 66-68)$

"Seperti tidak masuk akal tapi karena down, emosional...titik terdalam dalam kehidupan. Dilematisnya di antara benar atau salah...patokan selama ini standar dari Tuhan juga ngikuti aturan Negara" (IK, L, 39-42)

"Ada saatnya kita jadi idealis dan saat lain menjadi oportunis bisa berubah. Sepakat untuk pembelajaran. Hukum itu esensinya untuk apa. Hukum dibuat oleh manusia, dinamis. Sedangkan hukum Tuhan dengan religiusitas masing-masing hukumnya tidak bisa dipertentangkan. Teman ngajak minum minuman keras. Cicipin sedikit karena penasaran tapi moralitas agama membuat menyesal apalagi ingat bahwa 40 hari tidak diterima sholatnya, waktu itu agama terabaikan" (IK, Y, 103-111)

"Hukum agama lebih taat karena takut masuk neraka. Ada punishment. Hukuman berat membuat orang takut untuk kejahatan yang serius, kalau ringan menjadi tidak terlalu mengancam"'(IK, Y, 115-118)

Kepatuhan akan muncul ketika subjek penelitian mengingat bahwa pelanggaran akan berdampak panjang yaitu terkait dengan kebaikan dan ketegasan dosen serta konsekuensi dosa menurut agama.

\section{Peran Faktor Pribadi}

Faktor pribadi yang disebutkan subjek penelitian tersebut penting dalam pembuatan keputusan etis dan merupakan bagian dari kebiasaan maupun pencerminan pribadi seseorang (Faktor pribadi/FP).

"Pentingkan organisasi karena tanggung jawab organisasi menjadi sekretaris dan tidak ada yang bisa gantikan. Kemudian tugas kuliah masih bisa karena masih ada waktu. Namun meskipun sudah mempertimbangkan segala sesuatunya, dampaknya sempet tertekan karena harus bolos...bukan saya banget...bukan kebiasaannya" (FP, Y, 2529)

"Merasa ada tanggung jawab. Memang tanggung jawab ke orang tua penting namun ke organisasi perlu juga asal tidak mengganggu. Urgensitas yang penting tetapi tetap seimbangkan." (FP, Y, 72-76)

"Jadi pembelajarannya adalah kalau menghadapi masalah tetap pada pendirian, ternyata idealis itu memang diperlukan. dan jangan sekali-kali menggadaikan kebenaran. Proses pembelajaran berikutnya adalah dapat membreakdown kalau nanti melakukan sesuatu yang terjadi adalah A B C D demikian seterusnya. Bisa berpikir sistematis. Dampaknya titik tolak jika down pernah mengalami ini lho. Pilah mana yang mudhorotnya besar atau kecil", (FP, Y, 93-99)

"Jika dampaknya lebih banyak negatifnya lebih baik cari yang aman tapi sebisa mungkin bisa menghindari melanggar hukum untuk keputusan yang besar" (FP, Y, 100-102)

"Dilema terjadi karena salah manajemen. Organisasi dan kuliah sama penting dan sama-sama kewajiban. Seandainya bisa diatur waktu lebih baik atau manajemen pikiran yang baik, tidak akan terjadi dilema itu karena kelemahan kita akibat tidak disiplin terlalu santai". (FP, Y, 138-142)

"Pembuatan keputusan...saya sangat setuju yang menentukan adalah saat ini kebutuhan kita seperti apa tapi bisa juga karena mikir jangka panjang, menimbang keuntungan dan kerugiannya" (FP, Y, 143-145)

"Orang-orang idealis itu hebat, dapat mengalahkan dirinya sendiri, melawan kemalasan, berjuang dari seтиa rintangan" (FP, L, 49-50)

Beberapa subjek menyadari harus menahan godaan dengan pengaturan diri, disiplin diri, pertimbangan jangka panjang, kemampuan menimbang untung rugi, dan melawan kemalasan. 


\section{Pembahasan}

\section{Tema-Tema atau Isu-Isu Etis}

Mahasiswa menghadapi berbagai macam isu etis dalam dunia kampus. Isuisu etis tersebut terungkap dalam penelitian ini yaitu mencakup masalah akademik seperti membolos kuliah, pemalsuan tanda tangan pada daftar hadir yang biasanya terjadi karena teman menitip presensi atau mengijinkan teman memalsukan tanda tangannya agar tidak terhitung absen, serta penjiplakan (plagiat). Selain itu juga terdapat masalah sosial seperti perundungan, pelanggaran tertib lalu lintas, minum alkohol, pulang larut malam, melanggar aturan asrama, pencurian, hubungan seks pranikah, dan ide bunuh diri. Masalah sosial berkaitan dengan interaksi berupa konflik antar teman, berbohong kepada orang tua dan dosen. Masalah-masalah tersebut dapat mengganggu konsentrasi, bingung, kurang mampu berpikir jernih sehingga menimbulkan respon perasaan yang cukup bermakna, apalagi bila pelanggaran yang dilakukan tergolong berat.

Isu-isu tidak etis di kalangan mahasiswa di Perguruan Tinggi yang termasuk fatal dan ditemukan dalam penelitian ini yaitu plagiarism dan hubungan seksual pra nikah. Plagiarisme pada mahasiswa dipengaruhi oleh selfefficacy akademik dan prokrastinasi akademik secara simultan. Hasil penelitian menunjukkan bahwa apabila efikasi diri akademik tinggi ditambah dengan prokrastinasi akademik rendah, maka plagiarism menjadi rendah, demikian pula sebaliknya (Bukhori \& Dharmu'in, 2019) Sementara itu, untuk hubungan seksual pranikah telah diteliti sebelumnya oleh Pradisukmawati dan Darminto (2014) pada remaja usia 18-21 tahun di kota Surabaya yang pernah/ sedang menjalin hubungan dengan orang lain. Hasil penelitian menunjukkan terdeteksi adanya aktivitas seksual pada remaja dan tingkat religiusitas memengaruhi rendahnya aktivitas seksual.
Sebagai mahasiswa, ada subjek yang mengungkapkan harus menjaga moralitasnya. Individu menyadari bahwa ketika menunjukkan perilaku yang baik, lebih cenderung memiliki perasaan positif, tidak ada konflik, kebebasan dari perasaan bersalah atau penyesalan, dan ketenangan. Cooper dan Chen (2014) menyatakan bahwa ketika individu memperhatikan halhal etis, Individu akan lebih baik pada kondisi psikologisnya, dan sebaliknya. Individu dengan pengambilan keputusan etis memiliki emosi positif dan kepuasan hidup.

Mahasiswa telah mencapai usia dewasa awal, seharusnya mahasiswa telah memiliki kemampuan untuk membuat keputusan etis secara akurat. Menurut Kohlberg (Treviño dkk., 2014), orang dewasa berada pada tahap konvensional. Pada tahap ini individu memiliki kepedulian pada orang lain. Dengan asumsi bahwa mahasiswa adalah individu yang rasional, mereka telah cukup baik dalam mempertimbangkan hal yang baik dan buruk, manfaat dan kerugian dalam setiap situasi dan peluang. Mahasiswa diharapkan dapat berpikir lebih hati-hati.

Treviño dkk. (2014) menyebutkan pula untuk membuat keputusan etis, individu perlu memiliki kesadaran atau pemahaman etis terlebih dahulu. Hal itu menjadi syarat mutlak sebelum memutuskan. Ketika individu paham terhadap isu-isu etis tersebut, artinya individu dapat menilai baik buruk ataupun positif negatifnya, sehingga akurat dalam membuat pertimbangan dan selanjutnya bertindak secara tepat. Hastie dan Dawes (2010) berpendapat bahwa orang yang rasional memaksimalkan nilai konsekuensi dan selalu melihat kemanfaatan serta membuat prediksi berdasarkan perbandingan antara untung rugi.

Sebagian besar, subjek dalam penelitian ini mampu membuat keputusan etis, meskipun beberapa diantaranya juga menunjukkan keterlibatan dalam pelanggaran etis. Meskipun jumlahnya 
lebih sedikit, pelanggaran etis tidak boleh diabaikan karena berpotensi tumbuh menjadi kejahatan serius dalam kehidupan pribadi di masa mendatang. Hal ini konsisten dengan penelitian dari Harding dkk. (2004) serta penelitian Blankenship dan Whitley (2000).

Selama proses pembuatan keputusan, mahasiswa terkadang dilema. Pada titik tertentu, menjadi sadar terhadap masalah, memikirkannya dengan jelas, dan membuat penilaian moral yang akurat. Namun, terkadang terlambat menyadari hal ini. Salah satu alasan yang membuat mahasiswa sadar adalah ketika mulai mempertimbangkan konsekuensi masa depan dari tindakannya. Kahneman (2013) menjelaskan bahwa individu membuat keputusan dengan pertimbangan kognitif, dan individu berpikir lebih lambat melalui kontemplasi dan pertimbangan, terutama ketika keputusan memiliki konsekuensi tinggi.

\section{Faktor-Faktor yang Memengaruhi Pembuatan Keputusan Etis}

Mahasiswa yang menjadi subjek penelitian ini mengklaim bahwa ada beberapa kepercayaan yang memengaruhi keputusan dan perilaku, dan hal itu berasal dari internalisasi nilai-nilai agama dan nilai-nilai sosial. Orang Indonesia pada umumnya termasuk dalam masyarakat yang religius, dan taat pada perintah-perintah Tuhan. Pernyataan ini didukung oleh penjelasan dari para partisipan dalam penelitian ini. Subjek yakin bahwa jika taat, Tuhan akan memberikan pahala dan menempatkan di surga. Jika berperilaku buruk atau jahat, akan ada konsekuensi berat seperti dihantui oleh rasa bersalah, doa yang tidak diterima selama 40 hari bagi umat Islam, berdosa, dan kemungkinan masuk neraka tergantung pada kesalahan yang dibuat. Paloutzian dan Park (2005) menjelaskan bahwa agama terkait dengan nilai-nilai positif dan negatif dari perilaku, pengalaman, dan emosi manusia.
Nilai-nilai sosial dan contoh perilaku mungkin berasal dari orang tua, tempat belajar, dan teman sebaya dan hal itu tampak tercermin dari paparan subjek penelitian ini. Orang Indonesia, yang termasuk dalam masyarakat budaya Timur, sebagian besar fokus pada penciptaan suasana yang harmonis, sehingga menjadi cenderung patuh pada figur otoritas dan menyesuaikan diri dengan yang lain (Triandis \& Suh, 2002). Harris dkk. (2012) menyarankan bahwa sekolah, organisasi, pelayanan keagamaan, dan media seharusnya memperkuat nilai-nilai sosial dan perilaku yang sebelumnya dimiliki. Ferrell dkk. (1989) menggambarkan bahwa nilai-nilai positif atau negatif dipengaruhi oleh kematangan psikologis dan lingkungan.

Di Indonesia, mahasiswa dapat tinggal di asrama atau kos di kota lain, tetapi beberapa diantaranya masih tinggal bersama orang tua sehingga masih sering berhubungan langsung dan meminta beberapa saran sebelum membuat keputusan. Penelitian ini menemukan bahwa keluarga adalah salah satu faktor yang paling berpengaruh dalam kehidupan mahasiswa. Ferrell dkk., 1989) menggambarkan bahwa nilai-nilai positif atau negatif dipengaruhi oleh kematangan psikologis dan lingkungan. Pada awalnya, aturan yang ditetapkan oleh orang tua diinternalisasi oleh anak-anak dan menjadi pedoman berperilaku.

Menurut Harris dkk. (2012), pengaruh sosial adalah perubahan dalam pikiran, perasaan, sikap, atau perilaku sebagai akibat interaksi dengan individu atau kelompok. Sejalan dengan deskripsi dari Harris dkk. (2012), Crisp dan Turner (2010) menyampaikan bahwa pengaruh sosial mengubah pikiran, perasaan, perilaku orang atau kelompok dan hal itu terjadi ketika ada kehadiran orang lain. Pengaruh sosial ini mampu memfasilitasi penyebaran ide-ide nilai, sikap, dan perilaku. Ottaway dkk. (2017) menemukan bukti kuat tentang kecenderungan melakukan kesalahan 
karena tekanan untuk menyenangkan orang lain dan tuntutan pribadi untuk berhasil.

Berkaitan dengan konteks pengaruh sistem dalam institusi, subjek penelitian ini mencari celah dan alasan pembenar bagi pelanggaran etis, seperti menggunakan alasan kurangnya kejelasan dan ketegasan dalam penegakan aturan dan ada situasi yang memungkinkan serta kesempatan untuk melanggar aturan. Ferrell dan Gresham (Jones, 1991) menggambarkan bahwa ada beberapa faktor yang menyebabkan pembuatan keputusan yang etis dan tidak etis, yaitu pengetahuan tentang masalah etis, nilai-nilai, dan niat serta faktor-faktor lingkungan dan peluang.

Kebiasaan dibentuk oleh sifat-sifat yang dipelajari dari lingkungan sekitarnya. Orang akan relatif konsisten dari waktu ke waktu dalam perilakunya karena memiliki beberapa sifat pendukung. Kondisi ini tergantung pada sifat khusus yang dipelajari dan diamati (Larsen \& Buss, 2018). Kumpulan sifat membentuk karakter. Karakter yang berisi seperangkat sifat tersebut saling berinteraksi satu sama lain (Miller, 2014). Orang yang berkarakter baik mampu melawan godaan dan kemalasan serta tidak pernah menyerah dalam mengatasi hambatan.

Subjek penelitian ini menunjukkan beberapa karakteristik pribadi yang menonjol ketika menanggapi isu-isu moral. Karakter-karakter baik ini dikumpulkan dalam sifat-sifat yang relevan dengan moral, yang dapat disebut karakter moral. Aspek kognitif seperti pertimbangan konsekuensi masa depan, persepsi, makna dan pemahaman tentang isu-isu etis menjadi aspek penting dan utama dalam memahami masalah dan membuat keputusan. Keakuratan dalam menghadapi isu-isu moral sangat tergantung pada kapasitas kognitif ini.

Selanjutnya, aspek afektif seperti merasa sebagai orang bermoral (identitas moral), malu dan bersalah bila berperilaku tercela akan membuat subjek penelitian ini berupaya membuat dirinya sebaik mungkin. Apabila melanggar, muncul perasaan malu dan bersalah sehingga menyesali perbuatannya, atau merasa bukan dirinya. Hal ini termasuk dalam elemen identitas moral dari Cohen dan Morse (2014). Elemen identitas meliputi identitas moral, idealisme, dan relativisme moral, rasa malu dan rasa bersalah. Aquino dkk. (2009) menunjukkan bahwa identitas moral adalah mediator antara faktor situasional dan perilaku moral. Identitas moral ini adalah komponen penting yang bekerja dalam konsep diri. Seseorang yang memiliki identitas moral yang tinggi juga dapat melakukan perilaku peduli dan sebaliknya. Jika identitas moral rendah, orang itu akan menjadi egois.

Berdasarkan data dari subjek penelitian, elemen kemampuan yang terdiri dari pertimbangan konsekuensi masa depan, kontrol diri, disiplin, tanggung jawab, kesungguh-sungguhan, melawan kemalasan, merupakan faktor penting yang memengaruhi pembuatan keputusan etis. Hal ini termasuk dalam elemen kemampuan atau regulasi moral dari Cohen \& Morse (2014). Mahasiswa yang bermasalah dengan sifat-sifat tersebut, akan bermasalah pula dalam pembuatan keputusannya.

Penelitian dari Bushman dkk. (2012) menunjukkan bahwa orang dengan tingkat pertimbangan rendah untuk konsekuensi di masa depan memiliki risiko besar penyalahgunaan alkohol dan menjadi agresif. Orang-orang dengan tingkat pertimbangan konsekuensi masa depan yang tinggi dihubungkan dengan kapasitas mental yang lebih tinggi, terutama pada pemahaman, pemikiran logis dan analitis. Hal ini tidak mengherankan karena mahasiswa memperoleh lebih banyak wawasan, di pendidikan tinggi. Pada titik tertentu, mereka mungkin membuat kesalahan. Bukti ini membuat orang tersebut mengalami konflik dan perasaan negatif lainnya. Gino dkk. (2011) menunjukkan bahwa individu dengan penipisan ego atau kelemahan kontrol diri 
lebih cenderung bersifat manipulatif atau menipu.

Sama halnya dengan elemen kemampuan dan identitas moral, elemen motivasi menurut mahasiswa besar pula kontribusinya yaitu terkait dengan sifatsifat jujur, sederhana, bisa berempati terhadap orang lain, merasa ada keterlibatan moral (moral engangement), dan juga tidak memiliki sifat machiavellian. Hal ini termasuk dalam elemen kemampuan atau regulasi moral dari Cohen dan Morse (2014). Kebiasaan mahasiswa datang terlambat dengan memberikan alasan kebiasaan jam karet itu ditoleransi di masyarakat Indonesia, dan meminta teman-teman untuk memalsukan tanda tangan pada daftar hadir atau mengisi presensi sidik jari kemudian pergi, pelanggaran lalu lintas karena orang lain juga sama merupakan contoh-contoh ketidakterlibatan moral, Ketidakterlibatan moral adalah teori dari Albert Bandura (Moore dkk., 2012) dan dikembangkan untuk menjelaskan mengapa beberapa orang terlibat dalam pelanggaran tidak manusiawi tanpa perasaan bersalah.

Data menunjukkan bahwa pada mahasiswa ada yang memiliki salah satu dari kepribadian yang disebut machiavellian. Kecenderungan ini tampak secara kasuistik dalam pernyataan subjek penelitian yang cenderung pragmatis, meminta orang lain memahami dirinya dan kurang peduli orang lain. Menurut RuizPalomino dan Linuesa-Langreo (2018), Machiavellian merupakan karakteristik pribadi yang ciri-cirinya adalah cenderung bercorak pikir pragmatis dan cenderung amoral, berorientasi kepentingan pribadi, misalnya: untuk mendapatkan kekuasaan atau uang, dan dapat terlibat dalam penipuan dan eksploitasi terhadap orang lain.

Apakah orang harus memiliki kepribadian yang buruk untuk melanggar etis? Kenyataan menunjukkan tidak semua begitu. Orang baik pun dapat membuat keputusan yang buruk. Duska (2017) mengatakan bahwa ada enam faktor untuk menjawab pertanyaan tersebut. Faktorfaktor tersebut adalah: (1) kelemahan motivasi, (2) ketidaktahuan masalah moral, (3) sifat-sifat yang membuatnya mudah tergelincir/ terjebak, (4) kesombongan, (5) rasionalisasi, dan (6) kepatuhan terhadap otoritas. Faktor personal dan situasional adalah faktor penentu penting yang sama dalam pembuatan keputusan etis. Jadi menurut Duska (2017) orang baik dapat pula tergelincir melanggar etis, walaupun setelah itu menyesali perbuatannya.

Tang dan Liu (2012) mencatat bahwa keputusan mungkin benar-benar dipertimbangkan dalam pikiran, meskipun sebenarnya salah. Individu sangat mungkin dapat terlibat dalam rasionalisasi. Rasionalisasi adalah bias kognitif umum, kebiasaan berpikir dan bernalar yang membuatnya lebih mudah untuk menerima dan mengatur informasi, tetapi dapat menghambat perspektif orang dalam menilai bukti secara memadai.

\section{Strategi-Strategi Mengatasi Dilema Etis}

Individu sebenarnya telah memiliki strategi untuk membuat keputusan etis yang berbeda-beda satu sama lain. Beberapa di antara mahasiswa mengaku gagal menahan godaan dan membuat keputusan tidak etis hingga akhirnya menyesal. Individu juga mungkin gagal untuk memahami bahwa ada masalah moral yang dipertaruhkan dalam keputusan yang dibuat. Strategi yang dipilih dapat merupakan hal yang utama atau gabungan dari berbagai strategi. Tentu saja hal ini sangat tergantung pada kompleksitas permasalahan etis. Memilih dari sekian banyak alternatif dapat menimbulkan dilema. Dilema merupakan situasi ketidakpastian, oleh karena itu membutuhkan strategi untuk mengatasinya. Menurut Tversky dan Kahneman (1982) dalam masalah yang kompleks dan waktu yang dibutuhkan cukup lama, individu akan menambahkan berbagai variabel pendukung untuk memperlancar pembuatan keputusan. Dengan demikian, 
dapat dipahami munculnya strategi gabungan pada subjek penelitian karena memang mungkin menghadapi persoalan yang lebih kompleks dan rumit. Sebaliknya dalam masalah yang sederhana, individu hanya akan fokus bahkan pada satu variabel pendukung saja.

Melalui penelitian ini, paling tidak peneliti telah berupaya dalam hal menemukan dinamika pembuatan keputusan etis pada mahasiswa di Indonesia, terutama dalam hal isu-isu etis yang muncul dalam tema-tema, faktorfaktor dan strategi ketika membuat keputusan etis yang tentu saja lebih spesifik khas Indonesia. Penelitian serupa baru sebatas mengkaji tentang pembuatan keputusan etis dalam konteks mahasiswa yang kebanyakan berlatar belakang kondisi di Barat dengan perkembangan situasi sosial dan teknologi mutakhir. Peneliti menyadari bahwa penelitian ini mengandung keterbatasan. Faktor-faktor yang memengaruhi pembuatan keputusan etis belum teridentifikasi besaran sumbangan secara akurat dan penggalian data yang lebih meyakinkan sebenarnya dapat berlanjut pada stake holder penting lainnya.

\section{Simpulan}

Mahasiswa yang terlibat dalam penelitian ini menunjukkan kemampuan yang cukup memadai dalam pembuatan keputusan etis. Hal ini telah sesuai dengan kemampuan kognitif sebagai orang dewasa yang berpendidikan tinggi. Walaupun demikian, beberapa diantaranya masih menunjukkan tema-tema pembuatan keputusan tidak etis yang berupa: (a) plagiarisme, tidak hadir kuliah, terlambat datang, pemalsuan tanda tangan (masalah akademik); (b) berbohong pada dosen dan orang tua, kabur (masalah interaksi sosial dengan dosen dan orang tua); (c) konflik dengan teman, bullying, ide bunuh diri, merekayasa anggaran kegiatan kampus, (masalah interaksi sosial dengan teman dan kampus); dan (d) seks pranikah, pencurian, pelanggaran lalu lintas (masalah ketertiban umum).

Perilaku ini tidak dapat dibiarkan karena akan berpotensi tumbuh menjadi kejahatan serius dalam kehidupan pribadi dan profesional di masa depan apabila tidak segera ditangani dengan baik. Individu membutuhkan pemahaman tentang makna suatu isu etis untuk selanjutnya dapat memberikan evaluasi, pertimbangan, dan memunculkan intensi serta perilaku nyata.

Beberapa faktor sebenarnya sudah masuk dalam dimensi-dimensi karakter moral yaitu kemampuan mengontrol diri, motivasi moral dan identitas moral dan cukup berpengaruh. Sementara itu, persepsi, religiusitas, faktor sosial dan sistem dalam institusi seperti kepatuhan pada pihak otoritas, konformitas pada teman, penghargaan dan sanksi, serta peluang, juga menunjukkan kontribusi penting. Individu perlu konsisten menerapkan keputusan etis untuk itu diperlukan strategi tertentu. Adapun strategi yang dapat digunakan untuk meningkatkan pembuatan keputusan etis yaitu strategi yang terfokus pada risiko dan konsekuensi, prinsip hukum dan agama, saran atau masukan orang lain (teman, orang tua), dan karakter serta pengalaman pribadi.

\section{Daftar Pustaka}

Aquino, K., Freeman, D., Reed, A., Lim, V. K. G., \& Felps, W. (2009). Testing a social-cognitive model of moral behavior: The interactive influence of situations and moral identity centrality. Journal of Personality and Social Psychology, 97(1), 123-141. https://doi.org/ 10.1037/a0015406

Beeri, I., Dayan, R., Vigoda-Gadot, E., \& Werner, S. B. (2013). Advancing ethics in public organizations: The impact of an ethics program on employees' perceptions and behaviors in a regional council. Journal of Business Ethics, 112(1), 59-78. 
https://doi.org/10.1007/s10551-012$1232-7$

Blankenship, Kevin, L., \& Whitney, B. E. (2000). Relation of general deviance to academic dishonesty. Ethics and Behaviour, 10(1), 1-12. https://doi.org/10.1207/s15327019EB1 001_1

Brauer, J. R., Antonaccio, O., \& Tittle, C. R. (2013). Does religion suppress, socialize, soothe, or support? Exploring religiosity's influence on crime. Journal for the Scientific Study of Religion, 52(4), 753-774. https://doi.org/10.1111/jssr.12063

Bukhori, B., \& Dharmu'in. (2019). Plagiarism, self efficacy, and academic procastination on university students. Psympatic: Jurnal Ilmiah Psikologi, 6(2), 201-212. https://doi.org/10.15575/ Psy. v6i2. 6211

Bushman, B. J., Giancola, P. R., Parrott, D. J., \& Roth, R. M. (2012). Failure to consider future consequences increases the effects of alcohol on aggression. Journal of Experimental Social Psychology, 48(2), 591-595. https://doi.org/ 10.1016/j.jesp.2011.11.013

Cialdini, R. B., \& Goldstein, N. J. (2004). Social influence: Compliance and conformity. Annual Review of Psychology, 55(1), 591-621. https://doi.org/10.1146/ annurev.psych.55.090902.142015

Cohen, T. R., \& Morse, L. (2014). Moral character: What it is and what it does. In A. P. Brief \& B. M. Staw (Eds.), Research in Organizational Behavior. Elsevier. http://dx.doi.org/10.1016/j.riob.2014.0 8.003

Cooper, C. L., \& Chen, P. Y. (2014). Wellbeing: A Complete Reference Guide, Volume III, Work and Wellbeing. Wiley Blackwell

Creswell, J. W. (2015). Penelitian kualitatif dan desain riset (Memilih diantara lima pendekatan). Pustaka Pelajar.

Crisp, R. J. \& Turner, R. N. (2010). Essential Social Psychology: 2nd Edition. Sage.

Duh, M., Belak, J., \& Milfelner, B. (2010). Core values, culture and ethical climate as constitutional elements of ethical behaviour: Exploring differences between family and non-family enterprises. Journal of Business Ethics, 97(3), 473-489. https://doi.org/10.1007/s10551-0100519-9

Duska, R. F. (2017). Unethical behavioral finance: Why good people do bad things. Journal of Financial Service Professionals, 71(1), 25-28.

Ferrell, O. C., Gresham, L. G., \& Fraedrich, J. (1989). A synthesis of ethical decision models for marketing. Journal of Macromarketing, 9(2), 55-64. https://doi.org/10.1177/ 027614678900900207

Gino, F., Schweitzer, M. E., Mead, N. L., \& Ariely, D. (2011). Unable to resist temptation: How self-control depletion promotes unethical behavior. Organizational Behavior and Human Decision Processes, 115(2), 191-203. https://doi.org/ 10.1016/j.obhdp.2011.03.001

Gopinath, C. (2008). Recognizing and justifying private corruption. Journal of Business Ethics, 82(3), 747-754. https://doi.org/ 10.1007/s10551-0079589-8

Haidt, J. (2001). The emotional dog and its rational tail: A social intuitionist approach to moral judgment. Psychological Review, 108(4), 814834. https://doi.org/ 10.1037/0033295X.108.4.814

Harding, T. S., Carpenter, D. D., Finelli, C. J., \& Passow, H. J. (2004). Does academic dishonesty relate to unethical behavior in professional practice? An exploratory study. In Science and Engineering Ethics, 311-324.

Harris, J. K., Carothers, B. J., Wald, L. M., 
Shelton, S. C., \& Leischow, S. J. (2012). Interpersonal influence among public health leaders in the United States department of health and human services. Journal of Public Health Research, $\quad 1(1), \quad$ e12. https://doi.org/10.4081/jphr.2012.e12

Hastie, R., \& Dawes, R. M. (2010). Rational choice in an uncertain world: The psychology of judgement and decision making. SAGE Publications.

Heckler, N. C., \& Forde, D. R. (2015). The role of cultural values in plagiarism in higher education. Journal of Academic Ethics, 13, 61-75 https://doi.org/ 10.1007/s10805-014-9221-3

Hughes, J., \& McCabe, D. (2006). Understanding academic misconduct. Canadian Journal of Higher Education. 36(1), 49-63.

Hurlock, E. B. (2006). Psikologi perkembangan. Erlangga.

Jones, T. M. (1991). Ethical decision making by individuals in organizations: An issue-contingent model. Academy of Management Review, 16(2), 366-395. https://doi.org/10.5465/amr. 1991.4278958

Kahneman, D. (2013). Thinking fast and slow. Farrar, Straus and Giroux https://doi.org/10.1007/s13398-0140173-7.2

Kalshoven, K., Den Hartog, D. N., \& de Hoogh, A. H. B. (2011). Ethical leader behavior and big five factors of personality. Journal of Business Ethics, 100(2), 349-366. https://doi.org/10.1007/s10551-0100685-9

Kouchaki, M., \& Desai, S. D. (2015). Anxious, threatened, and also unethical: How anxiety makes individuals feel threatened and commit unethical acts. Journal of Applied Psychology, 100(2), 360-375. https://doi.org/ 10.1037/a0037796

Larsen, R., \& Buss, D. (2018). Personality psychology: Domains of knowledge about human nature (6 th). McGrawHill Education.

Miller, C. B. (2014). Character and moral psychology. Oxford University Press.

Moore, C., Detert, J. R., Klebe Treviño, L., Baker, V. L., \& Mayer, D. M. (2012). Why employees do bad things: Moral disengagement and unethical organizational behavior. Personnel Psychology, 65(1), 1-46. https://doi.org/10.1111/ j.17446570.2011.01237.x

Muzdalifah, F., Afriyanto, H. B., Psikologi, J., Jakarta, U. N., Psikologi, J., \& Jakarta, U. N. (2014). Pengaruh konsep diri terhadap perilaku bullying. Jurnal Penelitian dan Pengukuran Psikologi, 3(2), 59-64 https://doi.org/10.21009/JPPP.032.03

Ottaway, K., Murrant, C., \& Ritchie, K. (2017). Cheating after the test: Who does it and how often?. Advances in Physiology Education, 41, 368-374. https://doi.org/ 10.1152/advan.00103.2016

Paloutzian, R. F., \& Park, C. L. (2005). Integrative themes in the current science of the psychology of religion. In Handbook of the psychology of religion and spirituality. The Guilford Press.

Perrin, R. D. (2000). Religiosity and honesty: Continuing the search for the consequential dimension. Review of Religious Research, 41(4), 534-544. https://doi.org/10.2307/3512319

Pradisukmawati, D. L., \& Darminto, E. (2014). Hubungan antara tingkat religiusitas dengan tingkat aktivitas seksual pada remaja akhir. Psympatic: Jurnal Ilmiah Psikologi, 1(2), 179185. https://doi.org/10.15575/ psy.v1i2.476

Reynolds, S. J. (2006). A neurocognitive model of the ethical decision-making process: Implications for study and practice. Journal of Applied Psychology, 91(4), 737-748. https://doi.org/10.1037/ 0021- 
9010.91.4.737

Ruedy, N. E., Moore, C., Gino, F., \& Schweitzer, M. E. (2013). The cheater's high: The unexpected affective benefits of unethical behavior. Journal of Personality and Social Psychology, 105(41), 531-548. https://doi.org/ 10.1037/a0034231

Ruiz-Palomino, P., \& Linuesa-Langreo, J. (2018). Implications of personsituation interactions for machiavellians' unethical tendencies: The buffering role of managerial ethical leadership. European Management Journal, 36(2). https://doi.org/

10.1016/j.emj.2018.01.004

Sonenshein, S. (2007). The role of construction, intuition, and justification in responding to ethical issues at work: The sensemaking-intuition model. Academy of Management Review, 32(4).

https://doi.org/10.5465/AMR.2007.265 85677

Tang, T. L. P., \& Liu, H. (2012). Love of money and unethical behavior intention: Does an authentic supervisor's personal integrity and character (ASPIRE) make a difference?. Journal of Business Ethics, 107(3), 295-312. https://doi.org/10.1007/ s10551-0111040-5

Treviño, L. K., den Nieuwenboer, N. A., \& Kish-Gephart, J. J. (2014). (Un)Ethical behavior in organizations. Annual Review of Psychology, 65(1), 635-660. https://doi.org/10.1146/annurev-psych113011-143745

Triandis, H. C., \& Suh, E. M. (2002). Cultural influences on personality. Annual Review of Psychology, 53, 133160.

https://doi.org/10.1146/annurev.psych. 53.100901.135200

Tversky, A., \& Kahneman, D. (1982). Judgement under uncertainty: Heuristic and biases. In D. Kahneman \& A.
Tversky (Eds.), Judgement under uncertainty. Cambridge University Press.

Widyasari, R., \& Aryastami, N. K. (2018). Sociology study for health risk behaviour of dating violence on Yogyakarta college students. Buletin Penelitian Sistem Kesehatan, 21(1), 48-59. https://doi.org/10.22435/ hsr.v21i1.95.48-59

Wirawan, J. (2017, September). No Title. BBC Indonesia.

Yeung F. P. F., \& Keup, J. R. (2009). Ethical decision-making in college: Choosing between right, wrong, and the space in between. A SERU Project Research Paper. 1-3. 